\title{
Explaining the Informal Sector in Indonesia from the Transaction Costs Perspective*
}

\author{
Yohanna M.L. Gultom \\ Faculty of Economics, Universitas Indonesia, Indonesia
}

\begin{abstract}
The informal sector in Indonesia is massive, and has become a challenge to the growth of the open market economy. Explanations of the cause of informality have shifted over time from structural dualism to excessive government regulation. This paper argues that merely focusing on the high cost regulation may not reveal the bottom line of informality. Assessment and elaboration of infomality need the help of the transaction cost approach that suggests that informality in the economy exists due to the high-transaction-cost institutional framework. To support the argument, this paper provides a preliminary study on the transaction costs borne by firms in the industrial manufacturing sector based on two industrial surveys conducted by BPS-Statistics Indonesia, which are the 2009 survey on medium and large-scale enterprises (MLEs) and the 2010 survey on micro and small-scale enterprises (MSEs). This paper shows that micro and small-scale enterprises with no legality bore the least transaction costs compared to those operating legally, both micro and small-scale, as well as medium and large-scale enterprises. Consequently, regulatory reforms aimed at reducing transaction costs, not merely aimed at reducing official costs and simplifying procedures, are the keys to achieving economic growth while ensuring full participation of the private sector.
\end{abstract}

\begin{abstract}
Abstrak: Sektor informal di Indonesia bersifat masif dan menjadi tantangan tersendiri bagi perkembangan ekonomi pasar terbuka. Berbagai penjelasan tentang penyebab dari informalitas dalam dunia usaha tersebut akhir-akhir ini telah bergeser dari penjelasan dualisme struktural kepada regulasi pemerintah yang berbelitbelit. Paper ini mengusulkan bahwa fokus yang terbatas pada regulasi yang mahal saja tidak akan mengungkapkan kenyataan yang sebenarnya dari informalitas. Telaah dan elaborasi atas informalitas membutuhkan bantuan dari pendekatan biaya transaksi yang mengusulkan bahwa informalitas dalam ekonomi muncul akibat adanya kerangka institution yang menimbulkan biaya transaksi yang tinggi. Untuk mendukung argumentasi tersebut, paper ini menyampaikan suatu studi awal tentang biaya transaksi yang ditanggung oleh perusahaan dalam sektor industri manufaktur berdasarkan dua survey industri yang dilakukan oleh BPS, yaitu Survey Industri Besar dan Sedang tahun 2009 dan Survey Industri Mikro dan Kecil tahun 2010. Paper ini menunjukkan bahwa perusahaan mikro dan kecil yang tidak memiliki legalitas
\end{abstract}

* A previous version of this paper, with the title of "The Role of Informal Sector in the Era of 'Global Shift': The Case of Indonesia," was presented during The Society for the Advancement of Socio-Economics (SASE) $24^{\text {th }}$ Annual Meeting, at Massachusetts Institute of Technology (MIT), Cambridge, USA, in June 28, 2012.

* Corresponding author's e-mail: yohanna.magdalena@ui.ac.id 
usaha menanggung biaya transaksi paling kecil dibanding perusahaan-perusahaan yang beroperasi secara legal, baik yang berskala mikro dan kecil, maupun menengah dan besar. Dengan demikian, reformasi kebijakan yang ditujukan untuk mengurangi biaya transaksi, bukan sekedar bertujuan untuk mengurangi berbagai biaya resmi dan menyederhanakan berbagai prosedur, merupakan kunci bagi upaya untuk mencapai pertumbuhan ekonomi dengan turut memastikan adanya partisipasi yang penuh dari dunia usaha.

Keywords: business environment; informal sector; institutional framework; micro and small-scale enterprises; transaction costs

JEL Classification: D23 (transaction costs); O17 (formal and informal sector).

\section{Introduction}

The rise of new emerging-market economies, especially in the East, which lead to a 'global shift' in the world economy and international trade, calls for Indonesia's attention to take part in the economic renaissance. As Indonesia's economy is characterized by a majority of micro and small-scale enterprises (MSEs), their role is significant in the economy. In 2010, they accounted for more than 99 percent of total enterprises and absorbed 94.59 percent of the workforce. Their major contributions are in terms of job creation and a safety net for the poor. Yet, compared to that of medium and large-scale enterprises (MLEs), they contribute relatively little to national output, only 43.66 percent compared to 56.34 percent from MLEs, and especially to non-oil exports, contributing 5.38 percent compared to 94.63 percent (Ministry of Cooperative and Small and Medium Enterprise in www.depkop.go.id). One specific characteristic of MSEs in Indonesia, as in most developing economies, is that of common informality. Meanwhile, commercial liberalization requires strong economic institutions that establish and secure exclusive property rights to support voluntary exchanges based on contracts. Informality would prevent firms from growth and competitiveness due to the absence of secure property rights and lack of access to strong law enforcement, credit and other business facilities.

Explanations of the causes of informality have shifted over time from structural dualism to excessive government regulation. Yet, this paper tries to approach the problem of informality from the transaction costs perspectives which originated from the study by de Soto (1989). This paper provides a preliminary study on the transaction costs borne by firms in the industrial manufacturing sector, to show that informality in the sector may exist partly due to the high-transaction-cost institutional framework. A comparison of transaction costs borne by firms in the industrial sector which are registered formally and those which operate informally will be made using national statistics on industry. The data is based on two recent surveys on industry, the 2009 survey on medium and large-scale enterprises (MLEs) and the 2010 survey on micro and small-scale enterprises (MSEs), taking three major provinces on the island of Java (DKI Jakarta, West Java and East Java) as the sample. In so doing, this paper attempts to show that government initiatives to ensure a better business environment for new entrants to start a business legally are necessary, but not sufficient for the firms in the informal sector. Empowering their access to 
legality through minimizing transaction costs is as important as the reformation of business regulations to increase their access to competition, growth and job creation, thus ensuring the poor people enjoy the benefit of the 'global shift.'

\section{The Challenge of Informality in the Manufacturing Sector}

In the manufacturing sector, MSEs become the source of income for people with low education, for females, and for the poor. In Indonesia, the 2010 manufacturing survey on MSEs shows that MSEs have created jobs for around 6.4 million people. However, 92 percent of them have not been registered legally, according to local law, and thus operate in the informal sector (MSE Survey; and BPS 2010, processed). ${ }^{1}$ Meanwhile, the World Bank's Entrepreneur Survey (2009) shows that around 30 percent of registered firms being surveyed, started their operations without being formally registered, and only considered the legality of the business when they planned to enlarge the business or enter the export market. A large portion of the informal sector in the economy would bring negative consequences. Informality can be a source of unfair competition for the formal, or registered firms, and also deprive the government of potential tax revenue (World Bank 2011). In addition, from the firm's perspective, doing business outside the formal structure also has implications. The absence of formal property rights may not give firms the incentives to increase their productivity, and thus realize full gain of their rights over the property used. It may also restrict the firms from having a self-enforcing type of contract in doing exchange, thus limiting their access to large- scale business and direct exports. These implications would end up as a high cost structure in doing exchange.

According to the result of the MSE Survey in 2010 (BPS, processed), informality also explains the differences between formal and informal MSEs in terms of capital, access to credit, as well as economic performance such as income, expenditure and value added. Although lack of capital is the major problem faced by MSEs, the informal MSEs found the problem more severe. Not only do they have less capital than the formal ones, usually 2.5 times less, but also they have much more limited access to various sources of capital. The majority of the informal MSEs (89.2\%) rely on their own personal finance as the source of capital, while only a small amount of the formal MSEs (10.8\%) do. Informality has caused them to have restricted access to formal credit due to the absence of legality and property rights. The consequence of their lack of capital is that their expenditure and income are also less than those of formal MSEs. The data also shows that the limited amount of added value in MSEs is largely contributed by the informal MSEs. The differences signify that informality has led to the low contribution by MSEs in the manufacturing sector to growth and competition. The informality has further hindered MSEs from growth in their capital. It is shown by fact that more informal MSEs (52.1\%) than formal MSEs (42.0\%) claim that they are not interested in borrowing money from a bank for their capital. When the bank is not the preferred option for formal MSEs, because of its high interest rates, it also restrains informal MSEs from accessing it due to its collateral requirements.

${ }^{1}$ The number refers to entrepreneurs who have not registered legally out of 2,732,724samples in the 2010 Manufacturing Survey on Micro and Small Enterprises, Central Bureau of Statistics (BPS), processed. 
The small contribution of MSEs in the manufacturing sector to GDP is because of their low productivity due to their limited access to primary sources of productivity's growth, i.e. capital, technology and skilled labor (Tambunan 2007). Several constraints have hampered MSEs from growth and productivity. However, studies show that the lack of legality may count as one important cause to MSEs' low performance (de Soto 1989; Jaramillo 2004; World Bank 2009; and Kaplan et al. 2007). Informal enterprise cannot obtain all the benefits that formality can bring. Informal firms, due to their lack of good equipment and trained personnel, produce low quality products. This situation makes copyrighting or trade marking, and the fulfillment of export procedures difficult and unattractive to these firms, thus many of the entrepreneurs focus not primarily on their firms growth, but rather on providing employment for family members. Doing Business report (2012) also states that firms in the informal sector typically grow more slowly, have poorer access to credit, and employ fewer workers. A study on starting business in Peru showed that informality was claimed as the second most commonly barrier after financing among Peruvian entrepreneurs (Jaramillo 2004: 10).

\section{Literature Review}

The explanation of the causes of informality has shifted over time from structural dualism to excessive government regulation (de Soto 1989; Kaplan et al. 2007; Djankov et al. 2002; and the World Bank 2009). Excessive governmental regulation, related to business start-up, is claimed to be the incentive for firms to operate in the informal sector (Jaramillo 2004; and Kaplan et al. 2007). In Indonesia's case, according to IMF Country Report (2010), onerous regulatory framework is one out of three major bottlenecks to business expansion, besides skilled labor shortages and poor infrastructure, indicating a high cost regulatory environment. The World Bank's report on Doing Business (2012) also showed that the overall business regulatory environment in Indonesia was not yet conducive for trade and investment, shown by the lengthy and onerous procedures for doing business there. ${ }^{2}$ The main challenge to the approach of excessive government regulation in the issue of informality in Indonesia, is that it cannot really explain why, in spite of many regulatory reforms already made, the profile of MSEs in Indonesia has not really change. Kaplan (2007) argued that if the main reason for informality is excessive regulation, then actually it is possible for firms to avoid the excessiveness through bribes. On the other hand, if firms choose to be informal simply to evade tax, then the explanation of excessive government regulation would have little significance to the issue of informality.

Meanwhile, institutional economists (North 1990; Benham and Benham 2001; Jaramillo et al. 2004; and Zylbersztajn et al. 2005) claim that costly regulation is only one indication of inefficient institutional framework that provides the structure for production and exchange in the economy. An unfavorable business regulatory environment will result in high transaction costs, ${ }^{3}$ in which the costs per exchange are much greater than the

${ }^{2}$ However, the real cost faced by entrepreneurs due to the regulatory environment has not been reflected in this study, since it measures only the official days and official costs required by the regulatory procedures.

${ }^{3}$ The concept of transaction costs itself has been originated in Coase's classics $(1937,1960)$ as the cost of using price mechanism. 
costs per exchange in other economies with good institutional framework for the the same good being exchanged. Eggertson (1990: 1415) explains that when information is costly, transaction costs appear as the result of some activities related to the exchange of property rights by individuals, which include: 1) the search for information about the distribution of price and quality of commodities and labor inputs, and the search for potential buyers and sellers and for relevant information about their behavior and circumstances; 2) the bargaining that is needed to find the true position of buyers and sellers when prices are endogenous; 3) the making of contracts; 4) the monitoring of contractual partners to see whether they abide by the forms of contract; 5) the enforcement of a contract and the collection of damages when partners fail to observe their contractual obligations; and 6) the protection of property rights against thirdparty encroachment, for example, protection against pirates or even against the government in the case of illegitimate trade.

These transaction costs appear not only because of the excessive and incoherent regulation per se, but also because of existing social institutions that give in to diversion activities, such as thievery, squatting, Mafia protection, and the norms of giving gratification. Thus, a broader concept of "business environment," or what North (1990) called the institutional framework, and Hall and Jones (1999) called social infrastructure, will take into account not only the formal aspects of institution (law, policy, and regulation), but also the informal aspect of institution that goes beyond government policy. According to Hall and Jones, favorable social infrastructure, which consists of institution and government policy, is one that will provide an economic environment that supports productive activities and encourages capital accu- mulation, skill acquisition, invention and technology transfer (1999: 84). Such institution that promote suppression against diversion would lead to a low transaction as individual capture the social returns to their actions as private action (North and Thomas 1973) or what property rights theorists may claim as the full internalization of externalities (Coase 1960; and Demzets 1968).

With this approach, North (1990) argued that firms come into existence to take advantage of profitable opportunities defined by the institutional framework. In an environment with high transaction costs, informal sectors may exist to provide a structure of exchange, yet such structure comes with high costs due to the lack of formal property rights and self-enforcing types of contracts when doing exchanges. Such an inefficient institutional framework eventually demands costs of transactions be borne by the firms having transactions in the market due to the problems of imperfect information, adverse selection, and the moral hazard they face. Therefore, any explanation about the issue of informality needs to refer to the concept of transaction costs that reflect the inefficiency in the institutional framework that governs production and transaction in the economy in its entirety. This concept reflects the overall complex sets of institution, both formal (legal codes and regulations) and informal (norms/rules and traditions), that determines the relevant prices faced by individuals in the market. This relevant price is thus refer to the cost of exchange that is the opportunity cost faced by an individual to obtain a good using a given form of exchange within a particular institutional setting (Benham and Benham 2001: 3). Therefore, the relevant price includes the price of the goods themselves plus the transaction costs of obtaining the goods. The transaction cost 
perspective will help reveal how inefficient institution may have affected firms' opportunity costs by operating in the informal sector.

\section{Methods}

While the significance is not questionable, measuring transaction costs is problematic since transaction costs and production costs are jointy determined, thus it is difficult to measure transaction costs separately. Besides, there are no specific data of transaction cost available in most statistics of industry. Some studies suggest how to do a measurement of transaction cost from a range of perspectives (See Wang 2003 for an extensive literature study about measuring transaction costs). This study will follow Benham and Benham (2001: 3) who suggest a new approach to measuring transaction cost by introducing the concept of "the costs of exchange." This approach helps in determining the non-marketed transaction from the perspective of the firm's cost structure. They refer the costs of exchange to the opportunity cost faced by an individual that captures both the cost of the item itself and the transaction costs incurred by the individual to obtain the item. This concept allows this research to approach the transaction costs by comparing opportunity cost alternatives available in the market, for example, between the opportunity costs faced by the registered and non-registered firms (firms operating in the informal sectors). This is important since, especially in the market with high transac- tion costs, many kind of transactions may not take place at all, or if a specific kind of transaction occurs, it may not occur in an open market with money prices. Comparing alternatives will help this research to estimate the potential transaction costs faced by individual firms and why certain choices are made.

Using the approach of cost of exchange, this study aimed to conduct an examination on the transaction costs incurred by MSEs, both formal MSEs and informal MSEs, compared to that of MLEs. ${ }^{4}$ This study used statistical data from the 2009 industrial survey on MLEs and the 2010 industrial survey MSEs, restricted to only 3 major provinces in Indonesia, DKI Jakarta, West Java and East Java, to provide a sample of the informal sectors in these provinces. The survey on MLEs covers only firms with legal status, thus the data represents the formal sector. The survey on MSEs covers both firms with and without legal status in the raw data, thus this research has the advantage of categorizing the sample into two groups, the one with legal status to represent the formal MSEs and the one without legal status to represent the informal MSEs, for the purpose of analysis. ${ }^{5}$

The analysis was made by comparing the cost structure and performance between the formal MSEs and informal MSE on one side and with the MLEs on the other side. The cost structure includes both production costs and transaction costs. The production costs cover four basic components of costs including: 1) costs for raw materials; 2) wage/salary of workers; 3) costs of fuel, lubricants and electricity; and 4) other expenses.

\footnotetext{
${ }^{4}$ Indonesian Central Bureau of Statistics (BPS) defines micro, small, medium and large-scale enterprises as those business units consist of 1-4 workers, 5-19 workers, 20-99 workers and more than 100 workers respectively.

${ }^{5}$ While studies usually categorize micro and small-scale with medium-scale enterprise (small and medium-scale enterprise or SME), regrouping them to micro and small-scale in one group and medium and large-scale in the other group will give further insight to discuss the informality issues.
} 
For the MLEs, "other expenses" covers six sub-components of: (a) rental and contract payments; (b) tax, industrial services; (c) interest paid on loans; (d) charitable contributions; (e) representation cost and royalties; and (f) other. ${ }^{6}$ However, from those six sub-components, category (f) "other" was excluded from the "other expenses" to become the proxy for transaction costs in MLEs. This "other" category includes: a) representation costs; b) royalties; c) management fees; d) promotion and advertising costs; e) water, postage, facsimile, and telephone costs; f) travel expenses; g) prevention of environment pollution costs; h) research and development expenses; and j) human resource development expenses. This category is taken as the proxy for transaction costs since it includes mostly expenses related to transaction-cost-related activities, such as acquiring information, conducting negotiations, making a contract or agreement, monitoring and enforcing the contract, and the protection of, and enforcing, property rights.

For MSEs "other expenses" in the production costs covers 10 sub-components: a) stationary; b) interests paid on loans; c) delivery, postage and telecommunication costs; d) services and maintenance; e) rental and contract payments; f) land leasing; g) third party industrial services; h) indirect tax (including entertainment and retribution); i) expenses for other-party services (such as services for accounting, promotion and advertising, etc); j) others (costs related to packaging and supporting materials). Out of those 10 sub-components, category (c), (h), and (i) were excluded from the "other expenses" to be counted as the proxy for transaction costs in MSEs. For MSEs, since the survey records the component of other expenses differently, the proxy for transaction costs is the sum of the three sub-components of (c), (h), and (i) that are comparable to the proxy for MLEs as well as sensitive to the problem of the high transaction cost environment faced by MLEs.

Total expenditure is then regarded as the cost of exchange, which is equal to the production cost needed to transform input into output plus the transaction costs of doing the exchange in the market in order to produce the goods. Thus, the cost of exchange is measured by:

$$
\begin{aligned}
& \text { Cost of Exchange }_{(\text {MLE, MSE) }}= \\
& \text { Production Costs }_{\text {(MLE, MSE) }}+ \\
& \text { Transaction Costs } \\
& \text { (MLE, MSE) }
\end{aligned}
$$

\section{The Findings and Some Qualification to the Findings}

The findings confirm that the portion of transaction costs borne by MLEs is higher than that of MSEs. The portion of transaction costs in MLEs which count for 5.27 percent of the total opportunity costs of the firms is considered high since it has about the same value as the portion spent on fuel, lubricants and electricity $(5.70 \%)$ as well as other costs $(5.02 \%)$ which include rents, tax (excluding income and personal tax), industrial services and interest paid on loans. A relatively high ratio of transaction costs to cost of exchange faced by MLEs suggests that MLEs in general were facing a hightransaction-cost institutional framework or a high-transaction-cost economy in the manufacturing industry. Moreover, Figure 2 shows

${ }^{6}$ The category $\mathrm{f}$ ) other is used as the proxy for the transaction costs in this paper. 
Figure 1. Composition of Cost of Exchange in MSEs and MLEs in 3 Provinces in Indonesia (DKI Jakarta, West Java and East Java), 2009/2010 (\%)

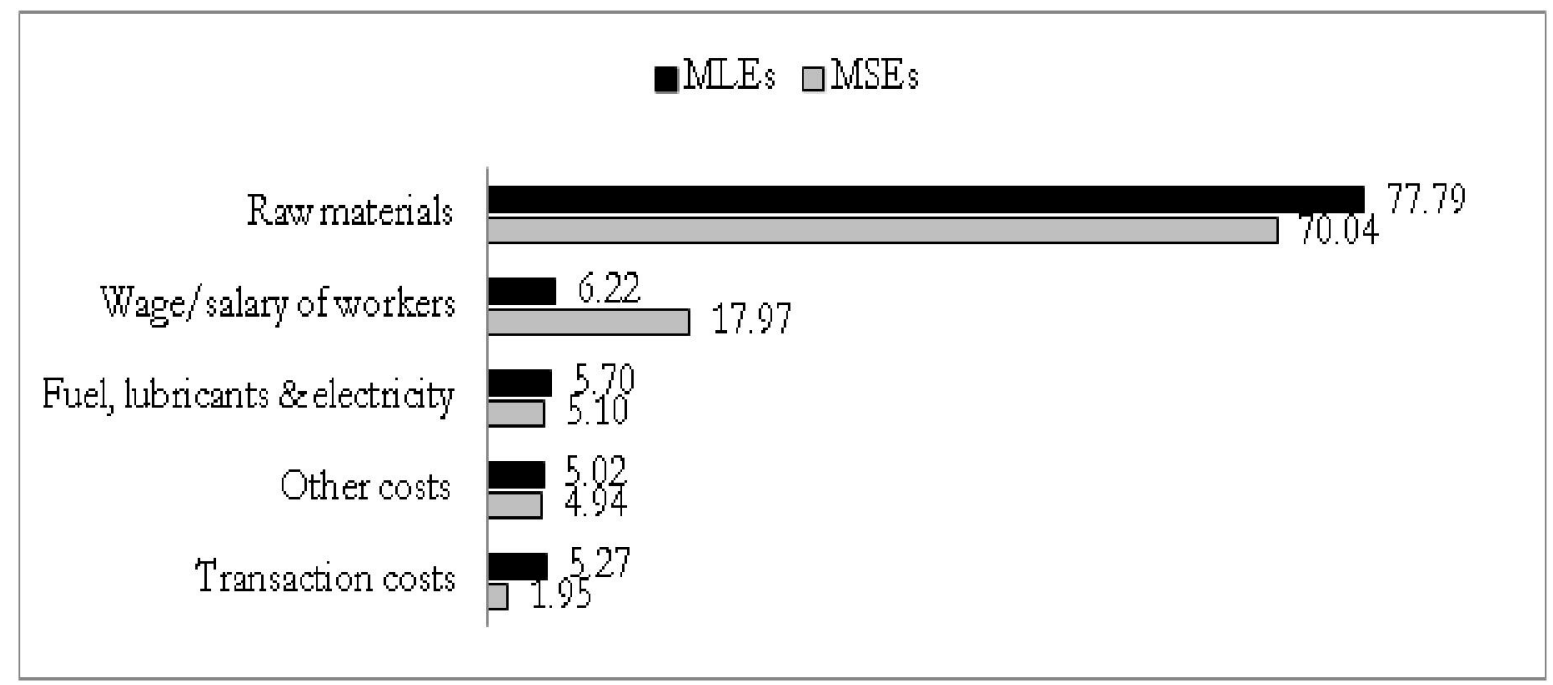

Source: 2009 Manufacturing Survey on MLEs and 2010 Manufacturing Survey on MSEs, Central Bureau of Statistics, processed.

Figure 2. Composition of Cost of Exchange among MLEs, Formal MSEs and Informal MSEsin 3 Provinces in Indonesia (DKI Jakarta, West Java and East Java), 2009/ $2010(\%)$

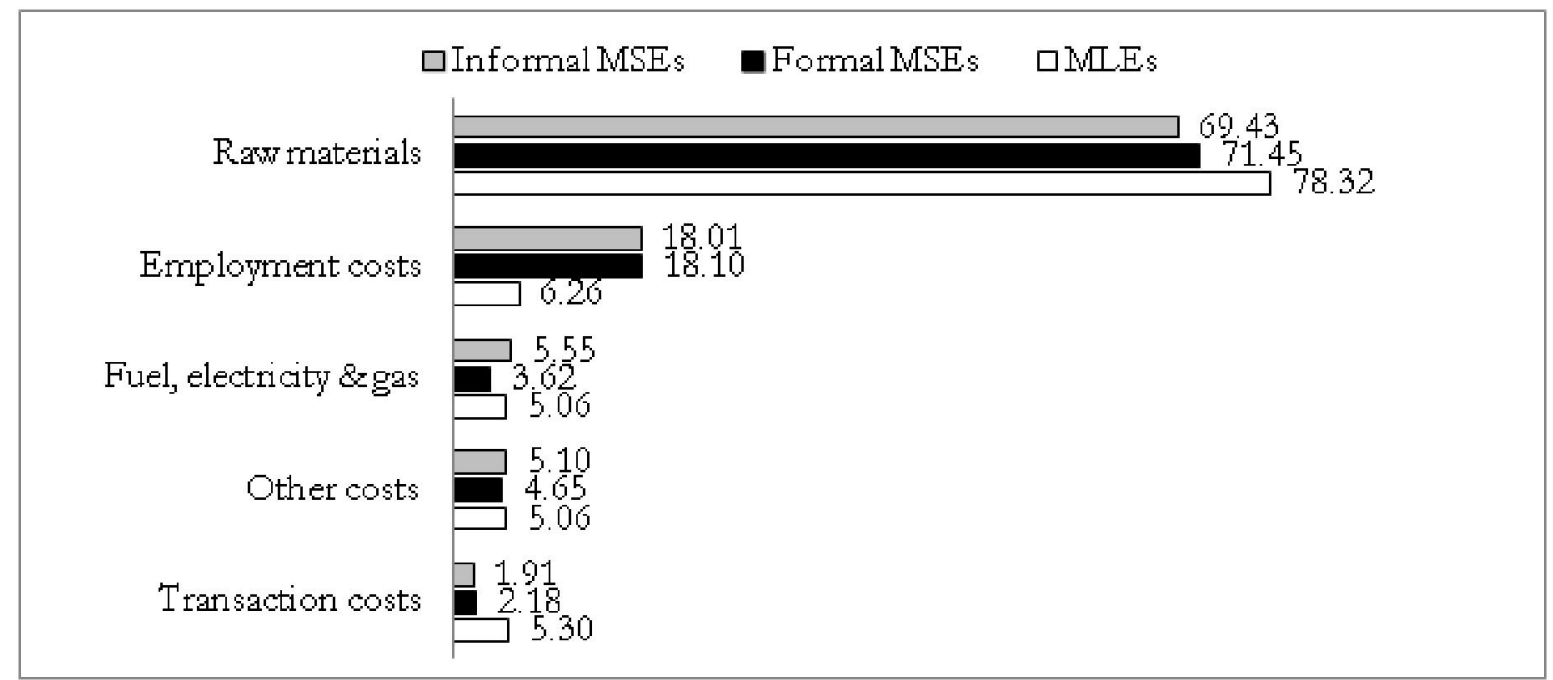

Source: 2009 Manufacturing Survey on MLEs and 2010 Manufacturing Survey on MSEs, Central Bureau of Statistics, processed. 
that MLEs have a higher portion of transaction costs than MSEs in general and informal MSEs in particular. By dividing the MSEs into formal MSEs and informal MSEs, the study shows that in terms of transaction costs, the gap between MLEs and informal MSEs is even wider $(3.39 \%)$. A previous study (Gultom 2012) showed that the high portion of transaction costs among MLEs in the industrial sector would affect firms' decisionmaking in the allocation of resources. As other cost components are given by the market price, the only component in cost of exchange that is under the firms' control is their labor cost. In fact, labor wages in Indonesia are set by the minimum wage controlled by the government, not by labor productivity.
However, the high-transaction-cost economy, or the inefficient institutions would have influenced firms' cost structure with some qualifications. First, the effect of a hightransaction-cost economy on the firms' cost structure is determined by the scale of the firms, and the legal status they have. The high-transaction-cost economy may have more impact on the MLEs than on the MSEs. Nevertheless, it may have impacted the informal MSEs the least. The characteristics of MLEs explain this finding. MLEs tend to have more capital intensive technology by having more expenses in raw materials and less expense in labor. However, the fact that MLEs count for almost 3 times higher than the proportion of transaction costs borne by

Table1. Composition of the Cost of Exchange by Type of Enterprise in 3 Provinces in Indonesia, 2009/2010 (Rp. 000)

\begin{tabular}{lrrrrrr}
\hline \multirow{2}{*}{ Cost of Exchange } & \multicolumn{2}{c}{ MLEs } & \multicolumn{2}{c}{ Formal MSEs } & \multicolumn{2}{c}{ Informal MSEs } \\
\cline { 2 - 7 } & \multicolumn{1}{c}{ Mean } & $\mathbf{0}$ & \multicolumn{1}{c}{ Mean } & \% & Mean & \% \\
\hline Raw materials & $3,670,848.63$ & 78.32 & $13,603.76$ & 71.45 & $5,937.71$ & 69.43 \\
Labor compensation & $293,569.55$ & 6.26 & 688.73 & 18.10 & 474.92 & 18.01 \\
Fuel, gas, electricity, & $237,096.49$ & 5.06 & $3,447.28$ & 3.62 & $1,540.18$ & 5.55 \\
water & & & & & & \\
Other expenses & $237,096.49$ & 5.06 & 885.73 & 4.65 & 435.77 & 5.10 \\
Transaction Costs & $248,621.97$ & 5.30 & 415.33 & 2.18 & 163.62 & 1.91 \\
Cost of Exchange & $4,687,233.12$ & $\mathbf{1 0 0}$ & $19,041.18$ & $\mathbf{1 0 0}$ & $8,552.33$ & $\mathbf{1 0 0}$ \\
\hline
\end{tabular}

Source: 2009 Manufacturing Survey on MLEs and 2010 Manufacturing Survey on MSEs, Central Bureau of Statistics, processed.

Notes: Costs of MSEs are based on expenditures in June 2010 while costs of MLEs are based on monthly average expenditures during 2009. 
MSEs also suggests that the size of, and technology used by the MLEs may have affected the proportion of the transaction costs they faced. Meanwhile, MSEs might have a lower portion of transaction costs due to, among other factors, the characteristics of informality they have, characterized by the absence of property rights and the lack of asset specificity.

Furthermore, Table 1 shows that the portion of expenses for raw materials tends to decrease as the firm's size gets smaller and if informality exists. A similar trend is found in the case of the transaction costs. Compared to MLEs, the portion of the transaction costs to the cost of exchange is lower in formal MSEs, however, it is even more so in informal MSEs. As the portion of the transaction costs are seen to declined from MLEs to formal MSEs and from formal MSEs to informal MSEs, this would explain why the transaction cost would be a constraint on them, as the firms operate with legality and as those firms with legality grow into a bigger business. Although a conclusion about the strength of the relationship between the transaction cost and informality could not be drawn from this data, the findings clearly confirm that some firms in the informal sectors could escape the burden of transaction costs faced by those operating legally.

This finding suggests that there is a relationship between the transaction costs borne by the manufacturing sector, with the informality in the sector. According to North, firms come into existence to take advantage of profitable opportunities defined by the institutional framework of the business regulatory environment, reflected by the kind of technology they use. He explains, "with insecure property rights, poorly enforced laws, barriers to entry, and monopolistic restrictions, the profit-maximizing firms will tend to have short time horizons and little fixed capital, and will tend to be small scale" (North 1990: 67). In this situation, the informal sectors exist to provide a structure of exchange. Nevertheless, such structure comes at a high cost due to the lack of formal property rights and the self-enforcing type of contract in doing exchange (ibid).

Therefore, the massive and persistent informality in the manufacturing sector could also be explained by the high transaction costs faced by the industries. As firms become more formal, they may require more mechanisms to define and protect their property rights, for example, by making contracts, submitting to the applied regulation related to doing business, trading, exporting and importing, as well as employing workers. These activities require more costs in finding relevant price, negotiating the contract, enforcing and monitoring the contract, as well as using the facilitator services to obtain the goods/permits they need. In conclusion, the absence of formal property rights would allow informal MSEs to waive the transaction costs as they find these transaction costs too costly for their scale and state of business.

Second, the effect of a high-transactioncost economy on firms' cost structure is determined by the variance of local institutional framework. Table 2 shows that transaction costs vary across provinces. This variation indicates that the institutional framework, both the formal (law and regulation) and informal (business culture, trust, and norms) institutions, also varies among regions. The variance still confirms the trend suggested in previous discussions though, that formal MSEs tend to have a higher portion of transaction cost, based on provinces and the scale of enterprise. The ratios between each component to production costs and to cost of exchange are presented for the purpose of 
comparison. The cost structure presented below also suggests that the relevant price of manufacturing goods in the market is determined not only by the production costs but also by the transaction cost of obtaining the goods. Thus, the 5.3 percent of transaction costs faced by MLEs means that in general, the money price of industrial products has departed by 5.3 percent from the neo-classical economics' margin. Across the 3 provinces, West Java tends to have the higher portion of transaction costs compared to DKI Jakarta and East Java, especially among MLEs (5.74\%) and formal MSEs (2.36\%). While among the informal MSEs, the highest portion of transaction cost is found in DKI Jakarta.

Third, the effect of a high-transactioncost economy on a firm's cost structure is also determined by the firm's type of industry. In this case, the type of industry relates to the level of specificity of investment or technology. As explained by Williamson $(1975,1985,1996,2000)$, the cost of transaction tends to be higher when a transaction is characterized by higher frequency of trade, higher level of uncertainty in doing the transaction, and a higher level of asset specificity. Under the assumption that economic agents are not fully rational, but only boundedly rational (as they face costly information and uncertainty in the market), as well as opportunistic in nature(See Williamson 1979, 2000, 2002 for the new institutional economics' behavioral assumption of economic agent), such a transaction may lead to a higher cost of searching information, negotiating and concluding the contract, enforcing the contract, and other activities related to defining and protecting property rights.

Table 3 shows that the portion of transaction costs varies across 8 types of industry where most of the MSEs operate. The portion of transaction costs tend to be high in industries with a high level of investment specificity or technology used. Industries with the highest portion of transaction costs that are shows consistently across the scale of firms (MLEs, formal MSEs or informal MSEs) are the pharmaceutical and chemical product industries and other non-metallic mineral product industries Among MLEs, these industries are the garment industry $(7.55 \%)$ and pharmaceutical and chemical/ traditional product industry $(6.80 \%)$; among formal MSEs, they are pharmacy and chemi$\mathrm{cal} /$ traditional product industries $(4.55 \%)$ and other non-metallic mineral product industries (2.07\%); and among informal MSEs, they are other non-metallic mineral product $(3.62 \%)$ and pharmaceutical and chemical/ traditional product industries $(3.42 \%)$. 
Table 2. Component of Costs by Types of Enterprise during a Month (Rp. 000)

\begin{tabular}{lccccc}
\hline PROVINCE & \multicolumn{3}{c}{ Component of Costs (Mean) } & & \\
\cline { 2 - 4 } & $\begin{array}{l}\text { Transaction } \\
\text { Costs } \\
\text { (a) }\end{array}$ & $\begin{array}{c}\text { Production } \\
\text { Costs } \\
\text { (b) }\end{array}$ & $\begin{array}{c}\text { Cost of } \\
\text { Exchange } \\
(\mathbf{a}+\mathbf{b})\end{array}$ & $\begin{array}{c}\text { Ratio } \\
\text { (a) to (b) }\end{array}$ & $\begin{array}{r}\text { Ratio } \\
\text { (a) to (a+b) }\end{array}$ \\
\hline 3 Provinces & & & & & \\
MLEs & $248,621.97$ & $4,438,611.15$ & $4,687,233.12$ & 5.60 & 5.33 \\
Formal MSEs & $415,331.90$ & $18,625,849.68$ & $19,041,181.57$ & 2.23 & 2.18 \\
Informal MSEs & $163,621.89$ & $8,388,704.94$ & $8,552,326.83$ & 1.95 & 1.91
\end{tabular}

DKI Jakarta

$\begin{array}{lrrrrr}\text { MLEs } & 5,879,696.18 & 306,315.48 & 6,186,011.66 & 5.21 & 4.95 \\ \text { Formal MSEs } & 804.51 & 35,334.60 & 36,139.11 & 2.28 & 2.23 \\ \text { Informal MSEs } & 477.89 & 23,742.48 & 24,220.37 & 2.01 & 1.97\end{array}$

West Java

$\begin{array}{lrrrrr}\text { MLEs } & 4,341,272.07 & 264,423.45 & 4,605,695.51 & 6.09 & 5.74 \\ \text { Formal MSEs } & 432.73 & 17,887.08 & 18,319.81 & 2.42 & 2.36 \\ \text { Informal MSEs } & 178.76 & 9,313.55 & 9,492.32 & 1.92 & 1.88\end{array}$

\section{East Java}

MLEs

$$
\begin{array}{r}
3,094,865.21 \\
113.39
\end{array}
$$$$
175,126.98
$$$$
3,269,992.20
$$

5.66

Formal MSEs

$6,961.75$

$7,075.14$

1.63

1.60

Informal MSEs

95.62

$4,912.89$

$5,008.51$

1.95

1.91

Sources: 2010 Manufacturing Survey on MSEs and 2009 Manufacturing Survey on MLEs, Central Bureau of Statistics (BPS), processed.

Notes: Costs of MSEs are based on means of expenditures in June 2010 while costs of MLEs on monthly average expenditures during 2009. 
Table 3. The Average of Transaction Cost Spent in a Month by Types of Industry and Types of Enterprise in 3 Provinces (DKI Jakarta, West Java and East Java) in Indonesia, 2009/2010 (Rp.)

\begin{tabular}{|c|c|c|c|c|c|c|}
\hline \multirow[t]{2}{*}{ Type of Industry } & \multicolumn{2}{|c|}{ MLEs } & \multicolumn{2}{|c|}{$\begin{array}{l}\text { Formal } \\
\text { MSEs }\end{array}$} & \multicolumn{2}{|c|}{$\begin{array}{l}\text { Informal } \\
\text { MSEs }\end{array}$} \\
\hline & Mean & $\begin{array}{c}\% \\
\text { to } \mathrm{CoE}\end{array}$ & Mean & $\begin{array}{c}\% \\
\text { to } \mathrm{CoE}\end{array}$ & Mean & $\begin{array}{c}\% \\
\text { to } \mathrm{CoE}\end{array}$ \\
\hline Food and beverages & $279,736,727.50$ & 5.82 & $167,162.83$ & 1.57 & $106,377.54$ & 1.37 \\
\hline $\begin{array}{l}\text { Wood and products } \\
\text { of wood }\end{array}$ & $36,025,099.17$ & 4.14 & $88,066.67$ & 1.67 & $75,331.85$ & 2.82 \\
\hline Textiles & $98,411,260.00$ & 5.09 & $28,002.77$ & 0.44 & $43,927.09$ & 1.69 \\
\hline Garment & $74,373,608.33$ & 7.55 & $396,660.81$ & 1.81 & $175,468.32$ & 1.37 \\
\hline $\begin{array}{l}\text { Other non-metallic } \\
\text { mineral products }\end{array}$ & $239,750,919.44$ & 5.54 & $192,518.75$ & 2.07 & $209,662.01$ & 3.62 \\
\hline $\begin{array}{l}\text { Pharmacy, chemical, } \\
\text { and traditional products }\end{array}$ & $1,173,266,096.94$ & 6.80 & $126,800.00$ & 4.55 & $56,430.67$ & 3.42 \\
\hline $\begin{array}{l}\text { Leather and products } \\
\text { of leather }\end{array}$ & $65,685,621.11$ & 4.99 & $427,791.26$ & 0.94 & $359,608.88$ & 1.51 \\
\hline Automotive & $1,040,428,875.28$ & 4.93 & $180,000.00$ & 1.68 & $410,105.68$ & 2.37 \\
\hline
\end{tabular}

Sources: 2010 Manufacturing Survey on MSEs and 2009 Manufacturing Survey on MLEs, Central Bureau of Statistics (BPS), processed.

Note: CoE stands for cost of exchange

\section{Conclusion}

The high cost economy in the manufacturing sector is a double-edged sword, with implications to the growth and competitiveness of the sector in the era of 'global shift.' On one side, it restrains the growth and productivity of MLEs in the manufacturing sec- tor which account for 75.4 percent of total non-oil exports. On the other side, it restrains MSEs optimal participation in the growth and productivity of the sector due to the high rate of informality. Assessment and elaboration of these implications need the help of the transaction cost approach to show that there are significant relations between the transac- 
tion costs and the scale of firms, firms' investment specificity, local institutional framework, and the status of formality.

While efficiency in production costs mostly depends on firms' internal factors, such as the choice of technology used, labor productivity and capital intensity ratio, efficiency in transaction costs depends more on external factors, especially those from the social institution and government regulation. In this context, a good and effective economic institution would value social inclusion, thus promoting development and poverty reduction. The challenge is thus to have a business environment which is supportive to micro and small-scale enterprises, to assist them to optimally access the market in doing exchange, thus improving their productivity and job creation. Strengthening their access to information regarding business procedures, access to registering and ensuring property rights, access to credit, access to enforcing contracts, and access to conduct trading are major issues in regulatory reform efforts. Increasing such access requires a favorable social infrastructure that protects against diversion in the economy, thus minimizing minimizing transaction costs in the economy. Diversion includes expropriation, confiscatory taxation, corruption, as well as thievery, squatting, mafia protection, and so on (Hall and Jones 1999: 84). Consequently, regulatory reforms aimed at reducing transaction costs resulted from such high-transaction-cost economy which are not merely aimed at simplifying procedures and reducing official costs, are the key to achieving economic growth while ensuring full participation by the private sector.

This paper suggests that the existence of the informal sector in Indonesia could also be explained by the high transaction costs borne by entrepreneurs in the manufacturing sector. The findings would open the door of opportunity for future empirical research to investigate further how transaction costs would affect the informality in industries. Such research will provide essential information for future business regulatory reform. As Hall and Jones stated, in order to show the strong relationship between social infrastructure and output per worker, "Countries with corrupt government officials, severe impediments to trade, poor contract enforcement, and government interference in production will be unable to achieve levels of output per worker anywhere near the norms of western Europe, northern America, and eastern Asia" (1999).

\section{Reference}

Benham, A. 2001. The cost of exchange, ronald coase. Institute Working Papers.

Bhardwaj, R., and L. Brooks. 1992. The January anomaly: Effects of low shareprice,transaction costs, and the bid-ask bias. Journal of Finance 47: 553-74.

Coase, R. 1937. The nature of the firm.Economica 4: 386-405.

Coase, R. 1961. The problem of social cost. Journal of Law and Economics 3: 1-44.

Coase, R. 1988. The Firm, the Market and the Law. University of Chicago Press

Demsetz, H. 1968. The cost of transacting. Quarterly Journal of Economics 82: 33-53.

Soto, H. 1989. The Other Path. New York: Harper and Row. 
Djankov, S., C. McLiesh, and R. Ramalho. 2006. Regulation and growth. EconomicLetters 92.

Djankov, S., R. La Porta, F. Lopez-de-Silanes, and A. Shleifer. 2002.The regulation of entry. Quarterly Journal of Economics 117: 1-37.

Eggertsson, T. 1990. Economic Behavior and Institutions. Cambridge: Cambridge University Press.

Gultom, Y. M. L. 2012. Transaction cost in Indonesia: The case study of starting a business regulation. ACTIVE Program Policy Paper 4 (Apr). Indonesian Chamber of Commerce and Industry and European Union.

Hall, R. E., and C. I. Jones. 1999. Why do some countries produce so much more output per worker than others? The Quarterly Journal of Economics 114 (1) (February): 83-116. Oxford University Press.

International Monetary Fund Country Report on Indonesia. 2010. A Country Report.

International Labor Organization Regional Office for Asia and the Pacific. 2008. Labor and Social Trend in ASEAN 2008: Driving Competitiveness and Prosperity with Decent Work.

Jaramillo, M., N. Reategui, and C. Calderon. 2004. Starting a garment manufacturing firm in Peru: Background and case study. Ronald Coase Institute Research Report Series 1 (June).

Kaplan, D. S., E. Piedra, and E. Seira. 2007. Entry Regulation and Business Start-ups: Evidence from Mexico.

Kuncoro, A., Isfandiarni, and T. Jasmina. 2007. Monitoring investment climate in Indonesia (Round 3): A report from the mid of 2006 survey. LPEM Working Paper 15. LPEM-FE UI, Jakarta.

Narayan, D., R. Chambers, M. K. Shah, and P. Petesh. 2000. Voices of the Poor: Crying Out for Change. Washington, DC: World Bank

North, D. C. 1990. Institutions, Institutional Change and Economic Performance. Cambridge: Cambridge University Press.

Tambunan, T. 2007. Development of small and medium enterprises in a developing country: The Indonesian case. Journal of Business and Entrepreneurship.

Wallis, J. J., and D. C. North. 1986. Measuring the transaction sector in the American economy (18701970). In S. L. Engerman, and R. E. Gallman, Long-Term Factors in American Economic Growth (Ed.), with a Comment by Lance Davis. Chicago: University of Chicago Press.

Wang, N. 2003. Measuring transaction costs: An incomplete Survey. Ronald Coase Institute Working Papers.

Williamson, O. 1975. Markets and Hierarcbies. New York: Free Press.

Williamson, O. 1979. Transaction cost economics: The governance of contractual relations. Journal of Law and Economics XXII (2) (October): 233-61.

Williamson, O. 1985. The Economic Institutions of Capitalism. New York: Free Press.

Williamson, O. 2000. The new institutional economics: Taking stock, looking ahead. Journal of Economic Literature 38: 595-613.

Williamson, O. 2005. The economics of governance. American Economic Review 95 (2) (May): 1-18.

Word Bank. 2012. Doing Business 2012: Doing Business in a More Transparent World. Washington, DC: The World Bank Group.

Word Bank. 2012. Doing Business in Indonesia 2012. Washington, DC: The World Bank Group.

Word Bank. 2011. Doing Business 2011: Making a Difference for Entrepreneurs. Washington, DC: The World Bank Group.

Word Bank. 2011. Doing Business in Indonesia 2011. Washington, DC: The World Bank Group. 
Word Bank. 2010. Doing Business 2010: Reforming through Difficult Times, Washington, DC: The World Bank Group.

Word Bank. 2010.Doing Business in Indonesia 2010, Washington, DC: The World Bank Group.

Word Bank. 2009. Doing Business 2009, Washington, DC: The World Bank Group.

Word Bank. 2009. Enterprise Surveys: Indonesia Country Profile. Washington, DC: The World Bank Group.

World Economic Forum. 2011. The Global Competitiveness Report 2011-2012, Geneva: World Economic Forum.

Zylbersztajn, D., and C. Graça. 2002. Costs of business formalization: Measuring transaction costs in Brazil. Manuscript. 
